NASA Technical Memorandum 101387

\title{
Radiation Resistance and Comparative Performance of ITO/InP and $n / p$ InP Homojunction Solar Cells
}

(AASA-TY-101jC7) WALIAIICA FESISTAACE AAC WMAEAIIVE EFELCLMANCE OE IIC,ISE AND $D / F$

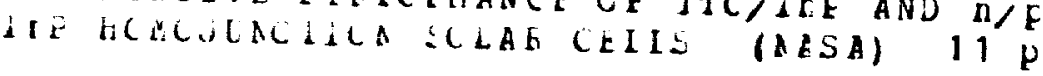

I. Weinberg, C.K. Swartz, and R.E. Hart, Jr.

Lewis Research Center

Cleveland, Ohio

and

T.J. Coutts

Solar Energy Research Institute

Golden, Colorado

Prepared for the 20th Photovoltaic Specialists Conference sponsored by the Institute of Electrical and Electronics Engineers Las Vegas, Nevada, September 26-30, 1988 
RADIATION RESISTANCE AND COMPARATIVE PERFORMANCE OF ITO/InP AND $n / p$ InP

HOMOJUNCTION SOLAR CELLS

\author{
I. We inberg, C.K. Swartz, and R.E. Hart, Jr. \\ National Aeronautics and Space Administration \\ Lewis Research Center \\ Cleveland, Ohio 44135
}

and

T.J. Coutts

Solar Energy Research Institute

Golden, Colorado 80401

\title{
SUMMARY
}

The radiation resistance of ITO/InP cells processed by dc magnetron sputtering is compared to that of standard $n / p$ InP and GaAs homojunction cells. After $10 \mathrm{MeV}$ proton irradiations, it is found that the radiation resistance of the present ITO/InP cell is comparable to that of the $\mathrm{n} / \mathrm{p}$ homojunction InP cell and that both InP cell types have radiation resistance significantly greater than GaAs. The relatively lower radiation resistance, observed at higher fluence, for the InP cell with the deepest junction depth, is attributed to losses in the cells emitter region. Diode parameters obtained from $I_{S C}-V_{O C}$ plots, data from surface Raman spectroscopy and determinations of surface conductivity type are used to investigate the configuration of the ITO/InP cells. It is concluded that these latter cells are $n / p$ homojunctions, the $n$-region consisting of a disordered layer at the oxide semiconductor interface.

\section{INTRODUCTION}

Indium phosphide solar cells have radiation resistance significantly greater than either silicon or gallium arsenide under both proton and electron irradiations (refs. 1 to 3 ). In addition air mass zero, total area efficiencies of 18.8 percent have been demonstrated and efficiencies approaching 22 percent appear feasible for homojunction InP solar cells (refs. 4 to 6 ). Although the prospects are promising with respect to radiation resistance and efficiencies, cost is a factor which requires increased effort (ref. 7). This being the case, indium tin oxide/indium phosphide (ITO/InP) solar cells present a lower cost, lower temperature, processing alternative to the more commonly encountered $n / p$ or $p / n$ homojunction InP cells (ref. 8). To date, however, there appears to be no published data on the performance of ITO/InP solar cells in a particulate radiation environment. Our previous research on solar cells in which the front surface oxide was an active cell component led to the conclusion that radiation induced degradation in the oxide was a significant factor in cell degradation (ref. 9). Hence, if ITO/InP cells are considered for use in space, one should not assume, in the absence of experimental evidence, that the InP homojunction radiation damage results apply to the oxide semiconductor cell. In addition to their radiation resistance, there remains the 
question as to whether the ITO/InP cells are heterojunctions, buried InP homojunctions or semiconductor-insulator-semiconductor (S-I-S) solar cells (refs. 8 to 11). In the present case, we have determined the performance of ITO/InP cells under proton irradiation and compared their performance, in a radiation environment, to that of $\mathrm{n} / \mathrm{p} \mathrm{InP}$ homojunction cells. We also present evidence to identify the configuration of the present ITO/InP cells. This latter information is of importance in theoretical modelling aimed at determining the parameters necessary to achieve optimum cell performance.

\section{EXPERIMENTAL}

The ITO/InP cells were fabricated at the Solar Energy Research Institute. The ITO was deposited, to a thickness of $850 \AA$, onto zinc doped p-type InP whose dopant concentration was $5 \times 10^{16} / \mathrm{cm}^{3}$. The ITO deposition was carried out at room temperature. The $n / p$ homojunction cells, obtained from the Rensselaer Polytechnic Institute and the Nippon Mining corporation, were processed by open and closed tube diffusion respectively (ref. 12). Junction formation in the cells obtained from RPI was achieved by diffusion at $700{ }^{\circ} \mathrm{C}$ for $25 \mathrm{~min}$, the AR coating being sio. The p-type substrate was zinc doped to a concentration of $5 \times 10^{16} / \mathrm{cm}^{3}$ while sulfur was employed as the n-dopant (ref. 12). The cells obtained from Nippon Mining were also processed on zinc doped substrates, the dopant concentration being $2 \times 10^{16} / \mathrm{cm}^{3}$. Sulfur diffusion was carried out at $T \approx 670{ }^{\circ} \mathrm{C}$ for $3 \mathrm{hr}$ (ref. 13). The AR coating for these latter cells was $\mathrm{SiO}_{2} / \mathrm{ZnS}$ (ref. 13) The cells were irradiated by $10 \mathrm{MeV}$ protons in the NASA Lewis Research Center's cyclotron. Performance measurements were carried out at NASA Lewis using a Xenon arc, X-25 solar simulator and an InP standard cell, calibrated at air mass zero in the NASA Lewis high altitude aircraft flight calibration program (ref. 14). Pre-irradiation cell parameters are shown in table I.

\section{RESULTS}

A plot of normalized efficiency versus fluence is shown in figure 1. Also shown, for comparison purposes, is data for an $n / p$ GaAs cell whose pre-irradiation AMO efficiency was 17 percent (ref. 7). In agreement with previous results, the radiation resistances of the present InP and ITO/InP cells are significantly greater than that of GaAs under $10 \mathrm{MeV}$ proton irradiation. Most significantly, the radiation resistance of the ITO/InP cell is comparable to that of the $\mathrm{n} / \mathrm{p}$ InP homojunction cell. The larger area $\left(2 \mathrm{~cm}^{2}\right)$ InP cell exhibits increased radiation resistance at the lower fluences while falling below the remaining InP cells at a proton fluence of approximately $6 \times 10^{11} / \mathrm{cm}^{2}$. From figures 2 and 3 , the radiation induced degradation in $I_{S C}$ is greater than that observed for $V_{O C}$ in the InP cells. This is consistent with previous results for InP observed after $1 \mathrm{MeV}$ electron irradiation (ref. 12). For the GaAs cells, the drop in normalized $I_{S C}$ is approximately equal to that observed for $V_{O C}$. This latter observation is contrary to that observed for GaAs under I MeV electron irradiation where the drop in $V_{0 c}$ was greater than that observed for $I_{S C}$ (ref. 12). However, it is noted that the GaAs cells in reference 12 were $p / n$ GaAs cells with an AlGaAs heteroface window while the present GaAs cells are $n / p$ homojunctions. 


\section{DISCUSSION}

The high optical absorption coefficients for InP would tend to make radiatlon induced losses in the cell's emitter region a significant component of the radiation induced degradation. In this connection, it is noted that the large area InP homojunction cells have junction depths between 0.2 and $0.3 \mu \mathrm{m}$ (ref. 13) while the smaller homojunction cells have junction depths $\sim 0.04 \mu \mathrm{m}$ (ref. 15). For further consideration of junction depth effects, we consider the normalized spectral responses shown in figures 4 and 5 . In the figures, the position of the junction was computed from the optical path length $1 / \alpha(\lambda)$ where $\alpha(\lambda)$ is the optical absorption coefficient at wavelength $\lambda$ (refs. 2 and 16). Because of its relatively larger junction depth, 50 percent of the radiation induced current loss occurs in the emitter region of the larger InP cell. On the other hand the emitter contribution of the smaller area cell is considerably less. These results suggest that the falloff at higher fluence, observed for the $2 \mathrm{~cm}^{2}$ cells, could be attributed to a radiation induced reduction in emitter minority carrier diffusion length such that it becomes less than the emitter width. Calculations of emitter diffusion length, using the cell's short wavelength spectral response, tend to support this suggestion. With respect to the increased radiation resistance at lower fluences, it is speculated that this may be due to better quality wafers used in processing the larger cells. This is supported by data presented in the remainder of the present paper.

As noted previously, the present ITO/InP solar cells exhibit radiation resistance comparable to that of the $n / p$ homojunction cells. Aside from this significant result, there remains the question of the configuration of the oxide semiconductor cells. To explore this in further detail, we consider $I_{S C}-V_{O C}$ data, obtained under varying light intensity, using the diode equation,

$$
I_{S C}=I_{O 1}\left(\exp \left(V_{O C} / A_{1} V_{T}\right)-1\right)+I_{O 2}\left(\exp \left(V_{O C} / A_{2} V_{T}\right)-1\right)+V_{O C} / R_{S h}
$$

where $V_{T}=k T / q, R_{s h}$ is cell shunt resistance and $A_{1}$ and $A_{2}$ are the junction quality factors. Iol is the injection-diffusion component of dark current and $\mathrm{I}_{\mathrm{O} 2}$ is the component due to recombination in the cells depletion region. Values for these parameters, obtained from the $I_{S C}-V_{O C}$ plots are shown in table II. The table also lists parameters for an additional InP cell processed by OMCVD (ref. 17). It should be noted that the table lists current densities rather than currents. Calculated values using equation ( 1 ), yield a good fit to the ISC-VOC curve of ITO/InP ( $\mathrm{I}_{\mathrm{O}}$ ig. 6). Similar fits are obtained for the $I_{S C}-V_{O C}$ data of the remaining InP cells.

Considering the injection diffusion component, $\mathrm{J}_{\mathrm{O}}$ a relatively low value for this component can be interpreted as an indicator of substrate quality. For example; the epitaxial cell, which is expected to have the best p-base layer quality yields the lowest value for this parameter. Thus, considering the remaining InP cells, the significantly lower values of Jol, obtained for the larger InP cell, indicates a higher quality p-base for this cell. This tends to confirm our previous comment concerning the quality of the material used in processing this cell.

Returning to consideration of the ITO/InP cell's configuration, if this cell were a true heterojunction, $\mathrm{J}_{0}$ l should be lower for this cell than the 
value obtained for homojunction cells (ref. 18). In fact, however, Jol for the ITO/InP cell has the highest value in table I. With respect to the recombination component $\mathrm{J}_{\mathrm{O} 2}$, one would expect this parameter to be relatively high for a heterojunction cell. This would especially be the case where a high number of interface states could be created by a large lattice mismatch between oxide and semiconductor. It is noted here that there is an excessive lattice mismatch (almost 100 percent) between the ITO and InP. Despite this, Jo2 for the ITO/InP cell has a value comparable to two of the $n / p$ homojunction cells and relatively lower than the remaining cell. Thus consideration of the injection-diffusion and recombination components tends to rule against the possibility of a heterojunction.

For completeness, it is noted that a tunneling term has been omitted from equation ( 1 ). In fact, the tunnelling mechanism is known to be a dominant mechanism in heterojunctions with large lattice mismatch (ref. 18). In the present case, a large tunnelling term would tend to increase the values obtained for either $\mathrm{J}_{\mathrm{O}}$ or $\mathrm{J}_{\mathrm{O} 2}$ or possibly both. However, for the present ITO/InP cells this is not the case for $\mathrm{J}_{\mathrm{O} 2}$. On the other hand, the large value obtained for $J_{0} l$ may be due to an additional contribution from tunneling. On balance however, the value obtained for $J_{0}$ in the case of ITO/InP is not excessively larger than that obtained for the small area InP cell. Thus it appears that the sum total of the present data argues against the heterojunction configuration.

To further investigate the nature of the ITO/InP cell configuration, the oxide-semiconductor interface layer was examined after first chemically etching away the oxide. Examination of the remaining InP surface by Raman spectroscopy revealed line broadening when compared to the Raman line obtained from single crystal InP. This indicates some degree of disorder in the interfacial layer. The possibility of the disordered layer being n-type was not investigated for the present cells. However a change in conductivity type, was determined by Hall effect measurements, on the interfacial layer of a sample in which the oxide was deposited under the same conditions as those employed in processing the present cells (ref. 19). Thus, the most likely configuration for the present ITO/InP cells is that of an $\mathrm{n} / \mathrm{p}$ buried homojunction with some disorder present in the n-type emitter layer.

\section{CONCLUSION}

It has been shown, under $10 \mathrm{MeV}$ proton irradiations, that;

1. The radiation resistance of ITO/InP cells processed by low temperature dc magnetron sputtering, is comparable to that of $n / p$ homojunction cells.

2. At high fluences, the relatively increased degradation observed in the larger area InP cells with relatively high junction depth is due to losses in the emitter.

3. It is suggested that the increased radiation resistance observed for the large area InP cells at low fluence is due to improved p-base quality.

4. The radiation resistance of ITO/InP and $n / p$ homojunction cells is significantly greater than that of GaAs. 
Aside from radiation damage considerations, the most likely configuration for the present ITO/InP cells is an $n / p$ buried homojunction solar cell where the n-region is a disordered InP layer at the oxide semiconductor interface.

\section{REFERENCES}

1. M. Yamaguchi, C. Uemura, A. Yamamoto, and A. Shibukawa, "Electron Irradiation Damage in Radiation Resistant InP Solar Cells," Jpn. J. Appl. Phys., Vol. 23, pp. 302-307, 1984.

2. I. Weinberg, C.K. Swartz, R.E. Hart Jr., and R.L. Statler, "Radiation and Temperature Effects in Gallium Arsenide, Indium Phosphide, and Silicon Solar Cells," in 19th IEEE Photovoltaic Specialists Conference, IEEE, Piscataway, NJ, 1987, pp. 548-557.

3. I. Weinberg, C.K. Swartz, and R.E. Hart Jr., "Potential for Use of InP Solar Cells in the Space Radiation Environment, "in 18th IEEE Photovoltaic Specialists Conference, IEEE, Piscataway, NJ, 1985, pp. 1722-1724.

4. C.J. Keavney and M.B. Spitzer, "Indium Phosphide Solar Cells Made by Ion Implantation," Appl. Phys. Lett., Vol. 52, pp. 1439-1440, 1988.

5. C. Goradia, J.V. Geier, and I. Weinberg, "Modelling and Design of High Efficiency Radiation Tolerant Indium Phosphide Solar Cells," in 19th IEEE Photovoltaic Specialists Conference. IEEE, Piscataway, NJ, 1987. pp. 937-943.

6. C. Goradia, J.V. Geier, and I. Weinberg, "Theory of the InP Shallow Homojunction Solar Cells," Solar Cells, to be published.

7. I. Weinberg and D.J. Brinker, "Progress in InP Solar Cell Research," in 23rd Intersociety Energy Conversion and Engineering Conference, Vol. 3 , American Society of Mechanical Engineers, New York, 1988, pp. 121-126.

8. T.J. Coutts and S. Naseem, "High Efficiency Indium Tin Oxide/Indium Phosphide Solar Cells," Appl. Phys. Lett., Vol. 46, pp. 164-166, 1985.

9. I. Weinberg, H.W. Brandhorst Jr., C.K. Swartz, and V.G. Weizer, "Radiation Damage in High Voltage Silicon Solar Cells," in Photovoltaic Generators in Space, ESA-SP-147, W.R. Burke, Ed., European Space Agency, Paris, France, 1980, pp. 129-135.

10. M.J. Tsai, A.L. Fahrenbruch, and R.H. Bube, "Sputtered Oxide/Indium Phosphide Junctions and Indium Phosphide Surfaces," J. Appl. Phys., Vol. 51, pp. 2696-2705, 1980.

11. R. Singh and J. Shewchun, "A Possible Explanation for the Photovoltaic Effect in Indium Tin Oxide on InP Solar Cells," J. Appl. Phys., Vol. 49, pp. 4588-4591, 1978.

12. I. Weinberg, C.K. Swartz, R.E. Hart Jr., S.K. Ghandhi, J.M. Borrego, K.K. Parat, and M. Yamaguchi, "Comparative Radiation Resistance. Temperature Dependence and Performance of Diffused Junction Indium Phosphide Solar Cells," Solar Cells, Vol. 22, pp. 113-124, 1987. 
13. H. Okazaki, T. Takamoto, H. Takamura, T. Kamei, and M. Ura, "Production of High Efficiency InP Solar Cells for Space Use," in Technical Digest-3rd International Photovoltaic Science and Engineering Conference, Japan Society of Applied Physics, Tokyo, Japan, 1987, p. 791.

14. H.W. Brandhorst Jr. and E.O. Boyer, "Calibration of Solar Cells Using High-Altitude Aircraft," NASA TN D-2508, 1965.

15. K.K. Parat, S. Bothra, J.M. Borrego, and S.K. Ghandhi, "Solar Cells in Bulk InP, Made by an Open Tube Diffusion Process, "Solid State Electron., Vol. 30, pp. 283-287, 1987.

16. O.J. Glembocki and H.Pillar, "Indium Phosphide (InP)," in Handbook of Optical Constants of Solids, E.D. Palik, ED., Academic Press, New York, 1985, pp. 503-576.

17. M.B. Spitzer, C.J. Keavney, S.M. Vernon, and V.E. Haven, "Indium Phosphide Shallow Homojunction Solar Cells Made by Metalorganic Chemical Vapor Deposition," Appl. Phys. Lett., Vol. 51, pp. 364-366, 1987.

18. H.J. Hove1, Semiconductors and Semimetals, Vol, 11, Academic Press, New York, 1975, p. 133.

19. T.J. Coutts, X. Li, M.W. Wanlass, and K.A. Emery, "Hybrid Solar Cells Based on DC Magnetron Sputtered Films of n-ITO on OMVPE Grown p-InP." in 20th IEEE Photovoltaic Specialists Conference, IEEE, Piscataway, NJ, to be published.

TABLE I. - PRE-IRRAOIATION PARAMETERS OF $\mathrm{n} / \mathrm{p}$ InP AND ITO/InP

\begin{tabular}{|c|c|c|c|c|}
\hline Cell & $\mathrm{ma}_{\mathrm{m}} \mathrm{C}_{\mathrm{cm}}^{\mathrm{C}}{ }^{2}$ & $v_{\mathrm{og}}$, & $\begin{array}{c}\mathrm{FF}, \\
\text { percent }\end{array}$ & $\begin{array}{c}\text { Efficiency, } \\
\text { percent }\end{array}$ \\
\hline $\operatorname{In} P\left(2 \mathrm{~cm}^{2}\right)$ & $\begin{array}{l}30.3 \\
30.5\end{array}$ & $\begin{array}{l}823 \\
823\end{array}$ & $\begin{array}{l}82.5 \\
82.4\end{array}$ & $\begin{array}{l}15 \\
15.1\end{array}$ \\
\hline $\begin{array}{l}\text { I T0/InP } \\
\left(0.718 \mathrm{~cm}^{2}\right)\end{array}$ & $\begin{array}{l}32.9 \\
32.2\end{array}$ & $\begin{array}{l}765 \\
757\end{array}$ & $\begin{array}{l}75.3 \\
70.3\end{array}$ & $\begin{array}{l}13.8 \\
12.5\end{array}$ \\
\hline $\operatorname{In} P\left(0.31 \mathrm{~cm}^{2}\right)$ & $\begin{array}{l}26.2 \\
24.8 \\
25.7 \\
24.7\end{array}$ & $\begin{array}{l}811 \\
809 \\
813 \\
804\end{array}$ & $\begin{array}{l}79.6 \\
81.6 \\
80.7 \\
78.9\end{array}$ & $\begin{array}{l}12.3 \\
11.9 \\
12.2 \\
11.2\end{array}$ \\
\hline
\end{tabular}

TABLE II. - DIFFUSION AND RECOMBINATION PARAMETERS

\begin{tabular}{|l|c|c|c|c|c|}
\hline \multicolumn{1}{|c|}{ Cell } & $\begin{array}{c}\text { Number } \\
\text { of cells }\end{array}$ & $A_{1}$ & $A_{2}$ & $\begin{array}{c}\mathrm{J}_{\mathrm{O}} \mathrm{l}_{2} \\
\mathrm{~A} / \mathrm{cm}^{2}\end{array}$ & $\begin{array}{c}\mathrm{J}_{\mathrm{A}} \mathrm{O}_{2} \\
\mathrm{Cm}^{2}\end{array}$ \\
\hline ITO/InP & 2 & 1.09 & 1.95 & $5.4 \times 10^{-14}$ & $4 \times 10^{-9}$ \\
InP (OMCVD) & 4 & 1.03 & 2.24 & $1.4 \times 10^{-16}$ & $4.1 \times 10^{-9}$ \\
InP(0.31 $\left.\mathrm{cm}^{2}\right)$ & 4 & 1.08 & 1.94 & $1.5 \times 10^{-14}$ & $4.1 \times 10^{-9}$ \\
InP $\left(2 \mathrm{~cm}^{2}\right)$ & 4 & 1.02 & 2.25 & $6.9 \times 10^{-16}$ & $2.5 \times 10^{-8}$ \\
\hline
\end{tabular}




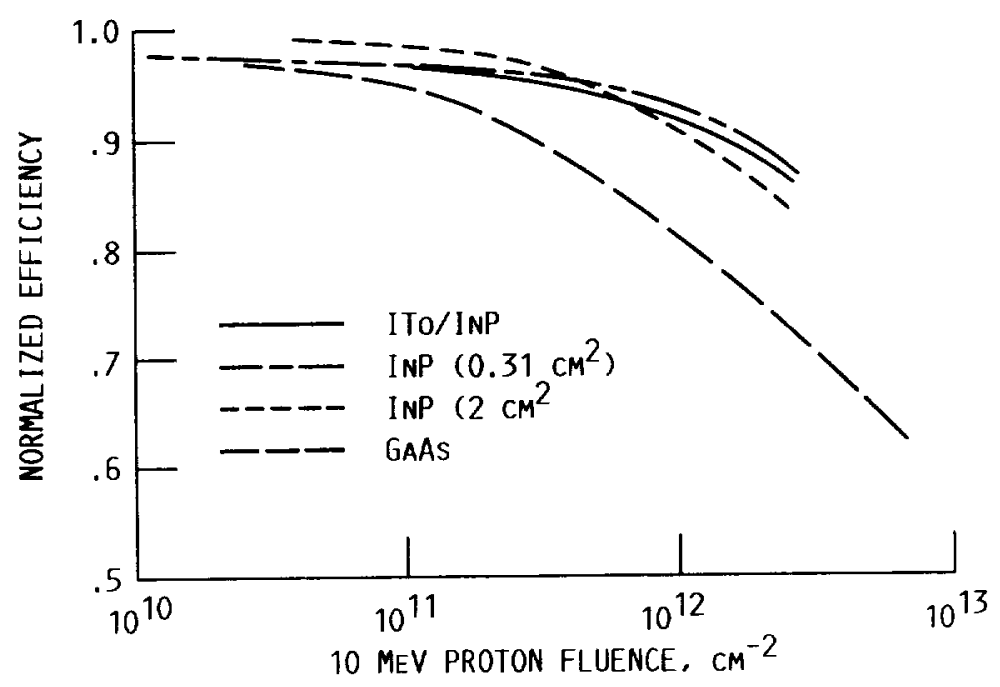

FIGURE 1. - NORMALIZED EFFICIENCY VERSUS PROTON

FLUENCE - ITO/INP, N/P INP, AND N/P GAAS.

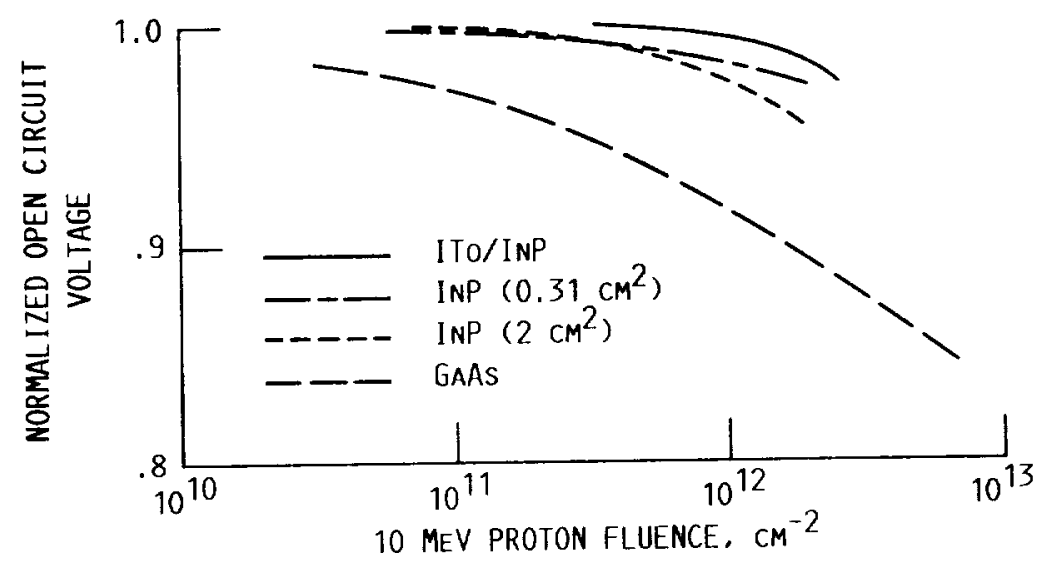

FIGURE 2. - NORMALIZED VOC VERSUS PROTON FLUENCE ITO/INP, N/P INP, AND N/P GAAS.

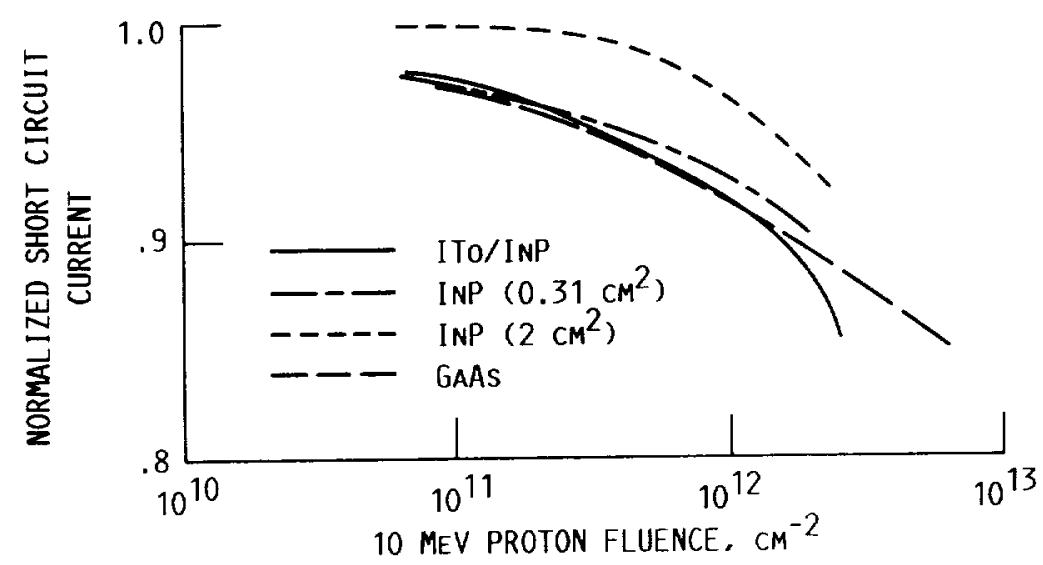

FIGURE 3. - NORMALIZED ISC VERSUS PROTON FLUENCE ITO/INP, N/P INP, AND N/P GAAS. 


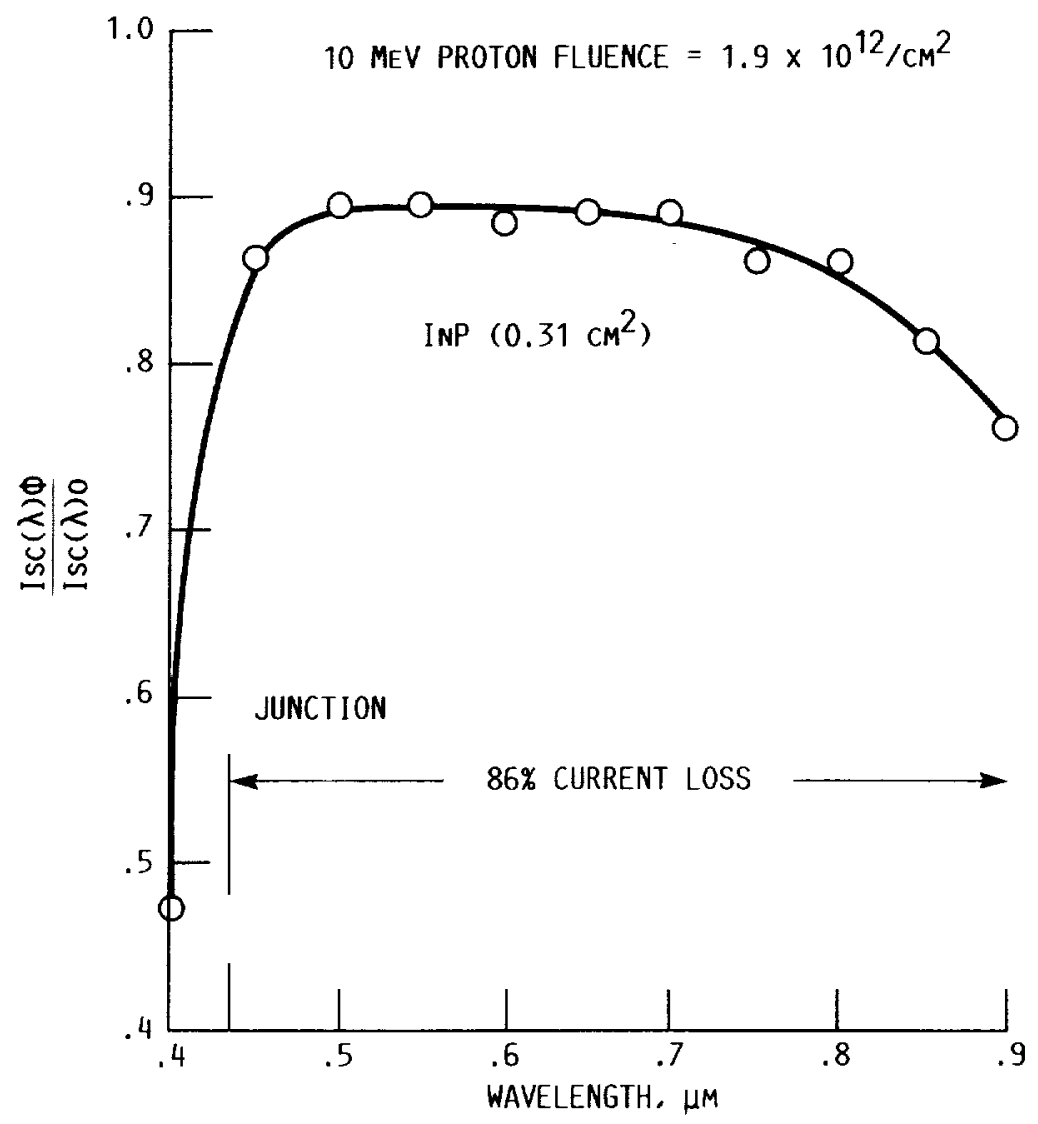

FIGURE 4. - NORMALIZED SPECTRAL RESPONSE OF SMALL AREA N/P INP HOMOJUNCTION CELL. 


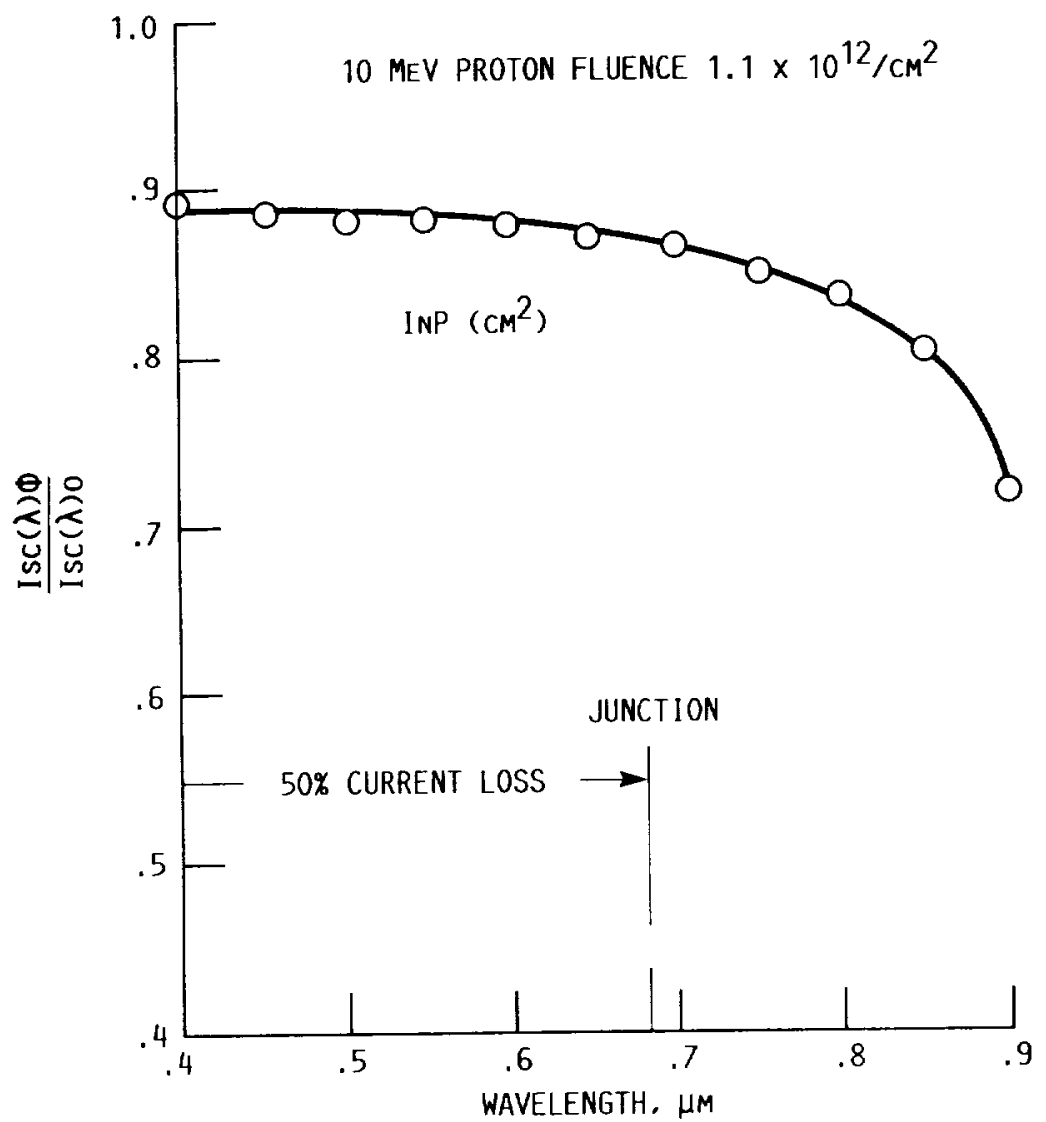

FIGURE 5. - NORMALIZED SPECTRAL RESPONSE OF LARGER AREA N/P INP HOMOJUNCTION SOLAR CELL.

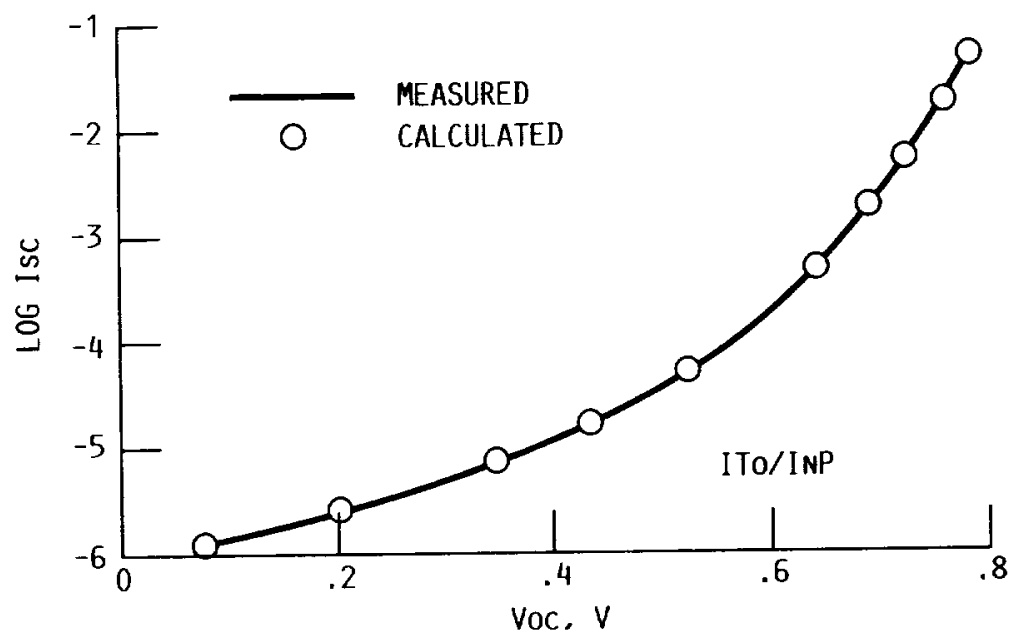

FIGURE 6. - LOG OF ISC VERSUS VOC FOR ITO/INP SOLAR CELLS. (SOLID LINE IS A PLOT OF MEASURED VALUES. DOTTED POINTS ARE CALCULATED USING EQ. (1).) 


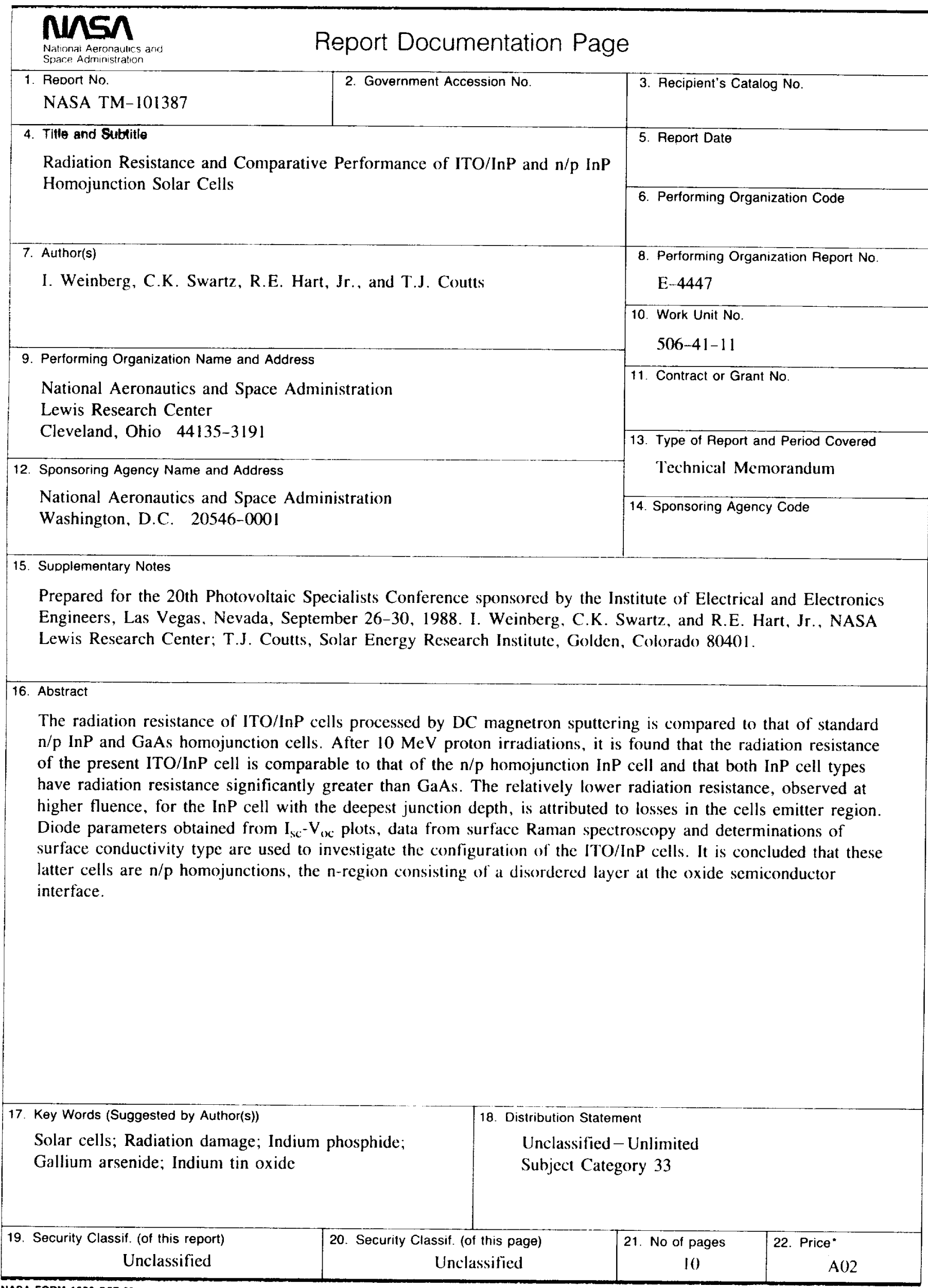

